\title{
Expression of cadmium carbonic anhydrase of diatoms in seawater
}

\author{
Haewon Park*, Patrick J. McGinn, François M. M. Morel \\ Department of Geosciences, Guyot Hall, Princeton University, Princeton, New Jersey 08544, USA
}

\begin{abstract}
The enzyme carbonic anhydrase (CA) plays a key role in the acquisition of inorganic carbon for photosynthesis in phytoplankton. Genes coding for the carbonic anhydrase CDCA, which can use either $\mathrm{Cd}$ or $\mathrm{Zn}$ as a metal center, are found in many diatom species and in natural seawater samples. The use of $\mathrm{Cd}$ in CDCA is the only known biological function of $\mathrm{Cd}$ and is thought to explain the nutrient-like concentration profile of $\mathrm{Cd}$ in the oceans. Here we report on the expression of CDCA in cultures of Thalassiosira weissflogii and in samples from the Equatorial Pacific and coastal New Jersey. CDCA1 is one of 2 types of CA found in T. weissflogii; its expression is highly modulated by $\mathrm{pH}$ changes and is induced by the addition of $\mathrm{Cd}$. Attempts to amplify cdca mRNA from samples of the Equatorial Pacific were not successful. However, protein bands from a sample incubated with $\mathrm{Cd}$ and analyzed by polyacrylamide gel electrophoresis (PAGE) reacted with CDCA antiserum, and a sample concentrated by immunoprecipitation yielded peptide sequences matching CDCA1. In samples from New Jersey coastal water, we found a high level of CDCA expression, which was inversely correlated with $p \mathrm{CO}_{2}$. CDCA is indeed expressed in ocean waters and is regulated in a manner consistent with its putative role in $\mathrm{CO}_{2}$ acquisition.
\end{abstract}

KEY WORDS: Carbonic anhydrase · Diatoms · Cadmium carbonic anhydrase - CDCA - Quantitative real-time RT-PCR · qRT-PCR

\section{INTRODUCTION}

Carbonic anhydrase (CA) - a zinc metalloenzyme that catalyzes the interconversion of bicarbonate and carbon dioxide in water-is ubiquitous in living organisms (Moroney et al. 2001). Thus far, 2 forms of CA have been found in the marine diatom Thalassiosira weissflogii: TWCA1, a $\delta$ - CA that uses $\mathrm{Zn}$ or Co at its active center, and CDCA1, a $\zeta$ - CA that uses $\mathrm{Cd}$ or $\mathrm{Zn}$ at its active center (Roberts et al. 1997, Lane \& Morel 2000a). CA is known to be important in the carbon concentrating mechanism (CCM) of phytoplankton, which elevates $\mathrm{CO}_{2}$ concentration in the vicinity of Rubisco to facilitate carbon fixation (Badger et al. 1998). Because Cd addition increases CDCA1 expression and growth rate in T. weissflogii cultures grown at low $\mathrm{Zn}$ and low $\mathrm{CO}_{2}$, the enzyme is thought to be a part of the CCM of this organism (Lane \& Morel 2000a).

In the oceans, where biologically available $\mathrm{Zn}$ is very low (Bruland 1989, Crawford et al. 2003), the use of Cd as a metal center in CA by phytoplankton is presumably an adaptation to low ambient $\mathrm{Zn}$. Because it represents the only known biological function of $\mathrm{Cd}$, it is thought that the use of $\mathrm{Cd}$ in CDCA may be responsible for the nutrient-like vertical profiles of Cd concentration in seawater (Lane et al. 2005).

In the model diatom Thalassiosira weissflogii, where it was originally discovered and isolated, CDCA1 consists of 3 repeated sequences with a high degree of identity (Lane et al. 2005). A DNA sequence found in the genome of $T$. pseudonana codes for a protein that is highly identical to a single repeat of CDCA1 (Armbrust et al. 2004). In a previ- 
ous study, we found that cdca-like genes are common in diatoms and in the field. We identified $c d c a$ in 10 diatom species analyzed with primers based on the sequences in T. weissflogii, and T. pseudonana. Similar genes with high degree of identity were also found in all natural samples of seawater tested, including samples from coastal New Jersey and the Arabian Sea (Park et al. 2007).

To better understand the possible role of CDCA in the physiology and ecology of marine diatoms and in the biogeochemical cycle of $\mathrm{Cd}$, we need to know where and under what conditions this enzyme is actually expressed and used in the oceans. Here we report on the conditions for CDCA expression in the laboratory and on our search for CDCA in the oceans. We used quantitative reverse transciption polymerase chain reaction (qRT-PCR), immunological and multidimensional liquid chromatography analyses to test natural and incubated samples from the surface waters of the Equatorial Pacific and the coast of New Jersey.

\section{MATERIALS AND METHODS}

Phytoplankton and culture medium preparations. All laboratory studies were conducted with the marine diatom Thalassiosira weissflogii grown at the ProvasaliGuillard Center for Culture of Marine Diatoms (CCMP) in Bigelow, Maine, USA. Diatoms (CCMP 1336) were grown in Aquil medium enriched with filter-sterilized nutrients, vitamins and trace metals according to Sunda et al. (2005) with some modifications; the metal stock solution was prepared without $\mathrm{Zn}, \mathrm{Cd}$ and $\mathrm{Co}$, and Synthetic Ocean Water was replaced by sterilized Gulf Stream Seawater (GSW). Stock solutions of Zn (100 $\mu \mathrm{M} \mathrm{Zn}, 0.1 \mathrm{mM}$ EDTA, pH = 2) and $\mathrm{Cd}(100 \mu \mathrm{M}, 0.1 \mathrm{mM}$ EDTA, $\mathrm{pH}=2)$ were prepared with sterilized milli-Q water, and an appropriate amount of $\mathrm{Zn}$ and/or Cd was added to each culture medium. The corresponding unchelated trace metal concentrations in cultures are calculated to be $\mathrm{Mn}^{\prime}=$ $10 \mathrm{nM}, \mathrm{Cu}^{\prime}=0.2 \mathrm{pM}$, and $\mathrm{Zn}^{\prime}=0.5$ to $15 \mathrm{pM}^{\prime} \mathrm{Cd}^{\prime}=6$ to $15 \mathrm{pM}$ at the presence of $0.1 \mathrm{mM}$ EDTA, calculated according to the conditional stability constants given by Sunda et al. (2005). The temperature of the incubator was maintained at $20^{\circ} \mathrm{C}$ under continuous light (123 $\mu \mathrm{mol}$ photons $\mathrm{m}^{-2} \mathrm{~s}^{-1}$ ).

Low Zn inocula preparation. Thalassiosira weissflogii cells were first inoculated from $\mathrm{f} / 2$ medium to $\mathrm{Zn}$ depleted ( $3 \mathrm{pM} \mathrm{Zn')} \mathrm{Aquil} \mathrm{medium,} \mathrm{and} \mathrm{transferred} 2$ to 3 times to consistently low $\mathrm{Zn}$ ( $3 \mathrm{pM} \mathrm{Zn}$ ) Aquil medium. The typical growth rate of $T$. weissflogii in 3 $\mathrm{pM} \mathrm{Zn'} \mathrm{was}<0.4 \mathrm{~d}^{-1}$. These cells were maintained at

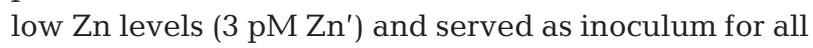
experiments.
Steady-state metal and pH experiment. Low Zn cells were transferred to experimental Aquil medium con-

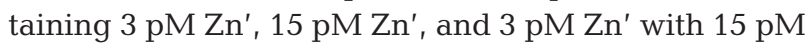
$\mathrm{Cd}^{\prime}$ in 3 different $p \mathrm{CO}_{2}$ levels with $\mathrm{pH}$ of $7.8(750 \mathrm{ppm})$, 8.6 (100 ppm) and 9.1 (40 ppm). pH was maintained by keeping cell density low ( $<8000$ cells per $\mathrm{ml})$. After 2 to $3 \mathrm{~d}$ of growth, cultures were collected by vacuum filtration ( $5 \mu \mathrm{m}$ pore size). All cell pellets were stored at $-80^{\circ} \mathrm{C}$ until analyzed.

Metal perturbation experiment. For our Cd-EDTA addition experiment, low Zn cells were transferred to experimental Aquil medium with $20 \%$ transferring volume and grown for $3 \mathrm{~d}$. When cell density reached 5000 to 8000 cells ml $^{-1}$, Cd-EDTA was added to each bottle with the final $\mathrm{Cd}^{\prime}=15 \mathrm{pM}$. Then cells were collected by vacuum filtration at $0.5,1,2,4,24 \mathrm{~h}$. Control cultures without Cd-EDTA addition were collected at time 0 (background, BG) and $24(24 \mathrm{C}) \mathrm{h}$. The control collected at time 0 served as background as it represents the cells' initial

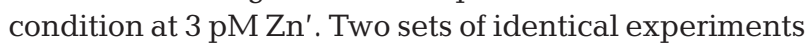
were performed on 2 different days. The measured $\mathrm{pH}$ was 8.3 in the first set and 8.4 in the second set at the time of Cd-EDTA addition. For the Zn-EDTA addition experiment, the following was different from the $\mathrm{Cd}$ EDTA experiment: $10 \mathrm{pM}$ of $\mathrm{Zn}$ ' was added to low $\mathrm{Zn}$ cells; cells were collected by vacuum filtration at $0,1,2$, $4 \mathrm{~h}_{\text {; }}$ measured $\mathrm{pH}$ was 8.5 at the time of filtration; each time point had duplicates; and $0.1 \mathrm{mM}$ of EDTA was used as a negative control to $\mathrm{Cd}$ and Zn-EDTA experiment. As described above, low Zn cells were transferred to experimental medium containing $3 \mathrm{pM} \mathrm{Zn'} \mathrm{and} \mathrm{after}$ being grown for $2 \mathrm{~d}$, EDTA was added to each culture medium for a final concentration of $0.1 \mathrm{mM}$. Cells were collected at 1, 4, 8 and $20 \mathrm{~h}$ to monitor the effect of EDTA. All time points were sampled in duplicate.

$\boldsymbol{p} \mathrm{CO}_{2}$ perturbation experiment. For the $p \mathrm{CO}_{2}$ decrease experiment, a few drops of $5 \mathrm{M} \mathrm{NaOH}$ were mixed into cultures containing low $\mathrm{Zn}$ with $\mathrm{Cd}$ ( $3 \mathrm{pM}$ $\mathrm{Zn}^{\prime}$ and $15 \mathrm{pM} \mathrm{Cd}$ ) to raise the $\mathrm{pH}$ from 7.8 to 8.5 . Cells were collected $0,0.5,1$, and $2 \mathrm{~h}$ after $\mathrm{NaOH}$ addition. All cells were flash-frozen in liquid nitrogen and stored at $-80^{\circ} \mathrm{C}$ until analysis. In a separate experiment, tanks of low- $\mathrm{CO}_{2}(100 \mathrm{ppm})$ were used to lower $p \mathrm{CO}_{2}$ from $750 \mathrm{ppm}$ to $100 \mathrm{ppm}$. Cells were collected $0,2,4,8,12$, and $30 \mathrm{~h}$ after $p \mathrm{CO}_{2}$ change. Time 0 , which served as background (BG), was collected before the $p \mathrm{CO}_{2}$ change, thus representing $750 \mathrm{ppm}$. For the $p \mathrm{CO}_{2}$ increase experiment, low $\mathrm{Zn}$ cells with high $\mathrm{Cd}(3 \mathrm{pM} \mathrm{Zn}$ ', $15 \mathrm{pM} \mathrm{Cd})$ were first prepared with $40 \mathrm{ppm} p \mathrm{CO}_{2}(\mathrm{pH}=9.1)$ and a drop of $50 \% \mathrm{v} / \mathrm{v}$ $\mathrm{HCl}$ (trace-metal grade) was added to shift $\mathrm{pH}$ from 9.1 to 8.1. Cells were collected $0,0.5,0.6,1,1.1,2$, and $2.1 \mathrm{~h}$ after $\mathrm{HCl}$ addition by vacuum filtration. Time 0 was collected before the $\mathrm{pH}$ shift, and serves as background (BG). 
RNA extraction, reverse transcription quantification and quantitative PCR analysis. The RNeasy Mini Column Kit (QIAGEN Sample \& Assay Technologies) was used to extract total RNA from the cultured diatom cells. Quantified RNA was then treated with DNase 1 to digest any possible DNA contamination (Invitrogen). Negative RT-PCR was performed before and after DNA digestion to confirm that no contaminating DNA was present in DNase1-treated RNA samples. DNase1 treatment was repeated as necessary. We determined the concentration of total RNA with RiboGreen-fluorescence dye (RiboGreen, RNA specific Quantitation Kit, Molecular Probes/Invitrogen) in a fluoro-spectrophotometer (Perkin Elmer). Equal amounts of RNA $(\sim 1 \mu \mathrm{g})$ were then used to synthesize cDNA using poly $\mathrm{p}(\mathrm{N})_{6}$ as primers (Amersham Biosciences' First Strand cDNA Synthesis kit). cDNA equivalent to $50 \mathrm{ng}$ of total RNA was used in each quantitative PCR. The primers for CDCA1 in Thalassiosira weissflogii were designed to target 196 base pairs of cdca1 amplicon between 867 and $1062 \mathrm{bp}$. The production of primer-dimers was checked on ethidium bromide-stained agarose gel after 40 cycles of PCR amplification and also by the dissociation curve. The oligonucleotide sequences of primers for cdca1 are as follows: 5'-CGGAGATCATTCCTCGGATA-3' (F) and 5'-GGCCAGGAGGTTGATGTAGA-3' (RC). We chose $18 \mathrm{~S}$ rRNA as a housekeeping gene in diatoms for endogenic transcript normalization. The primers for $18 \mathrm{~S}$ rRNA amplify 142 base pairs of amplicon and the oligonucleotide sequences were 5'-AGGTCTGTGAT GCCCTTAGA-3' (F) and 5'-CGCTTACTAGGAATTC CTCG-3' (RC). The PCR products of each pair of primers were ligated into pCR2.1-TOPO vector and used to transform TOP10 chemically competent Escherichia coli cells (TOPO TA cloning kit, Invitrogen). Plasmid DNA from positive clones was purified with the QIAprep Spin Miniprep kit (QIAGEN) and sequenced on the ABI Prism 310 Genetic Analyzer with M13 and T7 primers. Plasmid DNA concentration was quantified using PicoGreen (PicoGreen dsDNA Quantitation kit, Molecular Probes/Invitrogen), and the concentration was converted to the plasmid copy numbers. We made 10-fold serial dilutions with template concentrations ranging from $1 \times 10^{2}$ to $1 \times$ $10^{6}$ copies $\mu \mathrm{l}^{-1}$. Amplification profile for both cdca 1 and $18 \mathrm{~s}$ was $95^{\circ} \mathrm{C}$ for $10 \mathrm{~min}$, followed by 40 cycles of $95^{\circ} \mathrm{C}$ for $30 \mathrm{~s}, 55^{\circ} \mathrm{C}$ for $1 \mathrm{~min}$, and $72^{\circ} \mathrm{C}$ for $40 \mathrm{~s}$.

Equal amounts of total RNA (50 ng) were used for q-PCR analyses. SYBR Green DNA-binding dye (Brilliant SYBR Green QPCR Master Mix kit, Stratagene) and the Mx 3000 real-time thermocycler (Stratagene) were used following the manufacturer's instructions. Quadruplicates were run for each sample to test reproducibility. Standard curves were generated for every run. The efficiency of PCR was $95 \%<\mathrm{E}$ $<110 \%$ and standard curve slopes ranged between -3.3 and -3.5 . Dissociation curves were checked in all q-PCR runs. The relative amount of cdca1 transcript abundance was determined with a modified Pfaffl Method (Pfaffl 2001), $2^{-\left(\mathrm{Ct}_{(\mathrm{CDCA} 1)}-\mathrm{Ct}_{(18 \mathrm{~S})}\right)}$. For the absolute quantification of cdca1, the following equation was used: $y=-1.63 \operatorname{Ln}(x)+40.0$, where $y$ represents $\mathrm{Ct}$ values and $\mathrm{x}$ represents the absolute copy number of cdca1.

Sample collection from the Equatorial Pacific. DNA/RNA samples were collected from the surface water of the Equatorial Pacific near Peru onto Sterivex filters during the research cruises of the RV 'Knorr' (Woods Hole Oceanographic Institute) from October 18 to November 2, 2005, following the austral spring upwelling event. Surface water samples for $\mathrm{Cd} / \mathrm{NaOH}$ incubation were collected around 10:00 h each day using a trace metal-clean pump at a surface depth $<10 \mathrm{~m}$. Trace metal-clean 41 polycarbonate bags were filled with surface water and either $0.4 \mathrm{nM}$ total $\mathrm{Cd}$ (0.1 mM stock) or a couple of drops of ${ }^{14} \mathrm{~N} \mathrm{NaOH}$ were added to increase $\mathrm{pH}$ (up to 8.6). Samples were filtered before dark at $1,2,4$, and $8 \mathrm{~h}$ after treatment in duplicate on Sterivex filters. DNA/RNA samples were also collected from underway pipes and from CTD at depths <10 m. Chlorophyll a (chl a) concentrations were estimated based on the underway fluorescence measurement. All samples were stored frozen at $-70^{\circ} \mathrm{C}$ until analyzed. RNA/protein samples were then extracted with All-prep RNA/Protein extraction kit (QIAGEN) with methods adapted and modified from Hurt et al. (2001). Protein samples were then quantified with BCA protein assay kit (Pierce Biotechnology) and equal amounts $(50 \mu \mathrm{g})$ were loaded in each lane.

Peptide sequencing of protein samples from Equatorial Pacific. Quantified protein samples were further analyzed for immunoprecipitation using Protein A Agarose kit (Kirkegaard \& Perry Laboratories) following the manufacturer's instructions. Polyclonal antibody raised against overexpressed CDCA protein of Thalassiosira pseudonana was used to separate CDCA-like proteins from complex protein pools. Two equal amounts of protein were run on $10 \%$ sodium dodecyl sulphate (SDS) polyacrylamide gels side by side under the same condition. One part was followed by western blot analysis to confirm the size of separated molecule, and the other part was excised and the peptide sequences were analyzed as described by Delahunty \& Yates (2005). Eksigent Nano liquid chromatography coupled to tandem mass spectrometry system (2D-LC-MS/MS method) was applied for the peptide sequencing. Data acquisition was interfaced with the SEQUEST search algorithm. Databases of 
T. pseudonana to be used in SEQUEST searches were obtained from the Joint Genome Institute (accessed May 20, 2007, at http://genome.jgi-psf.org/Thaps3/ Thaps3.home.html).

Sample collection from coastal New Jersey. A 201 polycarbonate container was filled with surface seawater from LEO 15 (Long-term Ecosystem Observatory, Rutgers station, Tuckerton, NJ) on May 3, 2007. We filled 11 polycarbonate bottles with surface seawater, and monitored their $\mathrm{pH}$ and pigment changes for the next $4 \mathrm{~d}$ during growth under continuous light (123 $\mu \mathrm{mol}$ photons $\mathrm{m}^{-2} \mathrm{~s}^{-1}$ ). At 44,68 and $94 \mathrm{~h}$, samples were filtered onto $5 \mu \mathrm{m}$ isopore membrane and flashfrozen in liquid nitrogen. When the $\mathrm{pH}$ of unamended water naturally increased after $4 \mathrm{~d}$ in the laboratory culture room, $1 \mathrm{M}$ EPPS ( $\mathrm{pH}=7.2$ ) was added to lower $\mathrm{pH}$ from 8.1 to 7.5 . For RNA, DNA and protein analyses, phytoplankton were filtered on $5 \mu \mathrm{m}$ pore-sized isopore membranes and flash-frozen in liquid nitrogen, then stored at $-80^{\circ} \mathrm{C}$ until analyzed. RNA and protein were extracted using AllPrep RNA/Protein Kit (QIAGEN). RNA samples were then quantified and transcribed in the same manner as described above, except that PCR was performed with CdCA_418 primers with 30 cycles. For pigment analyses, phytoplankton were GF/F filtered, flash-frozen and stored at $-80^{\circ} \mathrm{C}$ until analyzed.

Western blotting analyses of Thalassiosira weissflogii cultures. About $200 \mathrm{ml}$ of cultured cells were harvested when the cell numbers reached 4 to $6 \times 10^{4}$ cells $\mathrm{ml}^{-1}$ by filtration on $5 \mu \mathrm{m}$ pore-sized membrane. Pellets were resuspended in water containing $10 \%$ SDS and $2 \mathrm{nM}$ of dithiothreitol (DTT). Samples were then boiled for about $5 \mathrm{~min}$ to completely denature the proteins. Total protein was quantified by modified Lowry method (Bio-Rad Laboratories) and then an equal amount of total protein $(10 \mu \mathrm{g})$ was loaded on $15 \%$ SDS polyacrylamide gels. Protein marker (Dual Colour Precision Plus Protein Standards, Bio-Rad) was run together with samples. After electrophoresis was carried out, the acrylamide gel was blotted to PVDF membrane for $2 \mathrm{~h}$ at $200 \mathrm{~mA}$ in tris-buffered saline transferring buffer with $0.25 \%$ Tween 20 (TBS [T]). The blotted PVDF membrane was then washed and immunostained with TpCDCA antisera (Y. Xu et al. unpubl. data). The samples were then incubated with antirabbit IgG alkaline phosphate conjugated secondary antibodies for the antigen-antibody reaction. The secondary reaction was detected with alkaline phosphatase and BCIP/NBT mix solution (Boehringer Mannheim). Bands were analyzed semi-quantitatively using QuantityOne software using background correction (Bio-Rad). Briefly, rectangular areas surrounding bands of the right size were boxed and the pixel intensity determined automatically. The identical procedure was carried out just below the band on the immunoblot, which served as the background value. All values were then normalized to the band intensity at time 0 (background).

CA assays. CA assays of phytoplankton collected from coastal New Jersey were conducted with the aid of a mass spectrometer attached via a membrane inlet to a thermo-regulated sample cell. Briefly, cells were collected on a $3 \mu \mathrm{m}$ polycarbonate filter under gentle vacuum and resuspended in $1 \mathrm{ml}$ of assay buffer (10 mM HEPES buffer, pH 8.2, 3.5\% w/v NaCl). The cells were concentrated further by a brief spin in a benchtop centrifuge followed by removal of the supernatant and resuspension in $50 \mu$ of assay buffer. The cell concentrates were snap-frozen in liquid N2 and stored at $-80^{\circ} \mathrm{C}$ until analysis, which was no more than $10 \mathrm{~d}$ from sampling. At the time of analysis, the cell pellets were thawed on ice and $40 \mu \mathrm{l}$ was injected directly into $0.96 \mathrm{ml}$ of assay buffer containing 0.3 to $0.5 \mathrm{mM} \mathrm{NaH}{ }^{13} \mathrm{C}^{18} \mathrm{O}^{18} \mathrm{O}^{18} \mathrm{O}$ in thermodynamic equilibrium with ${ }^{13} \mathrm{C}^{18} \mathrm{O}^{18} \mathrm{O}(\mathrm{m} / \mathrm{z}=49)$ at $\mathrm{pH} 8.2$. The relative concentrations of $\mathrm{m} / \mathrm{z} 49, \mathrm{~m} / \mathrm{z} 47\left({ }^{13} \mathrm{C}^{16} \mathrm{O}^{18} \mathrm{O}\right)$ and $\mathrm{m} / \mathrm{z}$ $45\left({ }^{13} \mathrm{C}^{16} \mathrm{O}^{16} \mathrm{O}\right)$ were followed over time and the ${ }^{18} \mathrm{O}$ enrichment of ${ }^{13} \mathrm{C}$ labeled $\mathrm{CO}_{2}$ was determined according to the following equation:

${ }^{18} \mathrm{O}$ enrichment $=\log _{10}[(49) /(49+47+45)] \times 100$

This relationship is linear with respect to time and the slope is directly proportional to CA activity. An external standard curve relating activity to the slope of the ${ }^{18} \mathrm{O}$ enrichment curve was constructed using various amounts of bovine CA. The $y$-intercept of this curve was taken as the enrichment slope determined in the absence of CA catalyst. Activities are reported here as Wilbur-Anderson units per mg chl a. Chl a was determined by extraction in $100 \%$ methanol according to Porra et al. (1989).

DNA sequencing and phylogenetic analyses. Sequencing procedure and sequence verification of cdca-like genes can be found in Park et al. (2007). Briefly, amplified DNA and cDNA products were cloned and positive colonies were analyzed for sequencing. New sequences were verified as cdcalike genes using JGI genomic database of Thalassiosira pseudonana (accessed April 28, 2007, at: www. jgi.doe.gov/). Deduced amino acid sequences from this study were aligned with the existing CDCA sequences database (Park et al. 2007) using ClustalW (accessed September 10, 2007, at: www.ebi.ac.uk/ Tools/ clustalw/). Phylogenetic trees were generated using the PAUP (4.0 beta version) software package and the Kimura two parameter model for inferring evolutionary distances. Bootstrap estimates were performed. All analyses were done with the NeighborJoining (NJ) analysis method. 


\section{RESULTS AND DISCUSSION}

\section{Conditions for the expression of CDCA1 in Thalassiosira weissflogii}

The enzyme CDCA1 was first isolated and identified from Cd-amended, low-Zn cultures of the diatom Thalassiosira weissflogii and we expected its expression to depend on the $\mathrm{Cd}$ and $\mathrm{Zn}$ concentrations in the medium. Further, in view of the role of CA in inorganic carbon acquisition in diatoms, we expected expression of CDCA1 to depend on the $p \mathrm{CO}_{2}$ of the medium. We thus performed experiments with varying concentrations of $\mathrm{Zn}$ and $\mathrm{Cd}$ in cultures of $T$. weissflogii. The $p \mathrm{CO}_{2}$ of the cultures was also varied by adjusting the $\mathrm{pH}$ with acid or base. Because our culture vessels were closed, the total dissolved inorganic carbon (DIC) concentration was constant (except for what was consumed by phytoplankton) and adjusting $\mathrm{pH}$ by adding acid or base changed the proportion of carbon present as $\mathrm{CO}_{2}$. In our system, $\mathrm{pH}$ of 9.1, 8.6 and 7.8, corresponded to $p \mathrm{CO}_{2}$ of 40,100 and $750 \mathrm{ppm}$, respectively. We measured the growth rate and CDCA1 expression under steady state conditions (Fig. 1). As in previous studies, near maximum growth rates were obtained for an unchelated $\mathrm{Zn}$ concentration, $\mathrm{Zn}^{\prime}$, of $15 \mathrm{pM}$, while $\mathrm{Zn}^{\prime}=3 \mathrm{pM}$ severely limited the growth rate (Fig. 1A,B). Partial restoration of growth was obtained in low $\mathrm{Zn}^{\prime}$ cultures amended with $\mathrm{Cd}$ to yield an unchelated $\mathrm{Cd}$ concentration, $\mathrm{Cd}^{\prime}$, of $15 \mathrm{pM}$ (Fig. 1C). At each $\mathrm{Zn}^{\prime} / \mathrm{Cd}^{\prime}$ treatment, changing $p \mathrm{CO}_{2} / \mathrm{pH}$ had a modest effect on growth, generally resulting in a slight increase in growth rate with increasing $p \mathrm{CO}_{2}$, as expected (Lane \& Morel 2000a).

For each treatment, we performed qRT-PCR of the total RNA extracted from the cultures to quantify the level of cdcal expression. As expected, the highest level of cdca1 expression was obtained under conditions of low $\mathrm{Zn}$ and added $\mathrm{Cd}$ at low $p \mathrm{CO}_{2}$ (Fig. 1F). This trend is qualitatively and quantitatively similar to the results obtained by Lane \& Morel (2000a) on the basis of ${ }^{109} \mathrm{Cd}$ labeling and quantification on protein gels; the amount of CDCA1 in their study increased approximately 4 -fold when $p \mathrm{CO}_{2}$ changed from $750 \mathrm{ppm}$ to $100 \mathrm{ppm}$ in low $\mathrm{Zn}$ ' high Cd' cultures, comparable to the increase in $c d c a 1$ transcript levels in our study (Fig. 1F). Surprising is the relatively high level of cdca1 expression measured in cultures with no $\mathrm{Cd}$ added. It seems unlikely that the very low background contaminant concentration of $\mathrm{Cd}$ in our medium $\left(\mathrm{Cd}^{\prime}=\right.$ $1.5 \mathrm{pM}$ ) could provide the metal centers for significant cellular concentrations of CDCA1. So either the measured mRNA of CDCA1 is not translated or the protein that is synthesized has a different or no metal center. (See later discussion on the use of $\mathrm{Zn}$ as a metal center in CDCA).

To understand the kinetics of the response in CDCA expression in diatoms upon changes in the chemistry of the culture medium, we first conducted 2 sets of experiment where low $\mathrm{Zn}\left(\mathrm{Zn}^{\prime}=3 \mathrm{pM}\right)$ and low $p \mathrm{CO}_{2}(\mathrm{pH}=8.3$
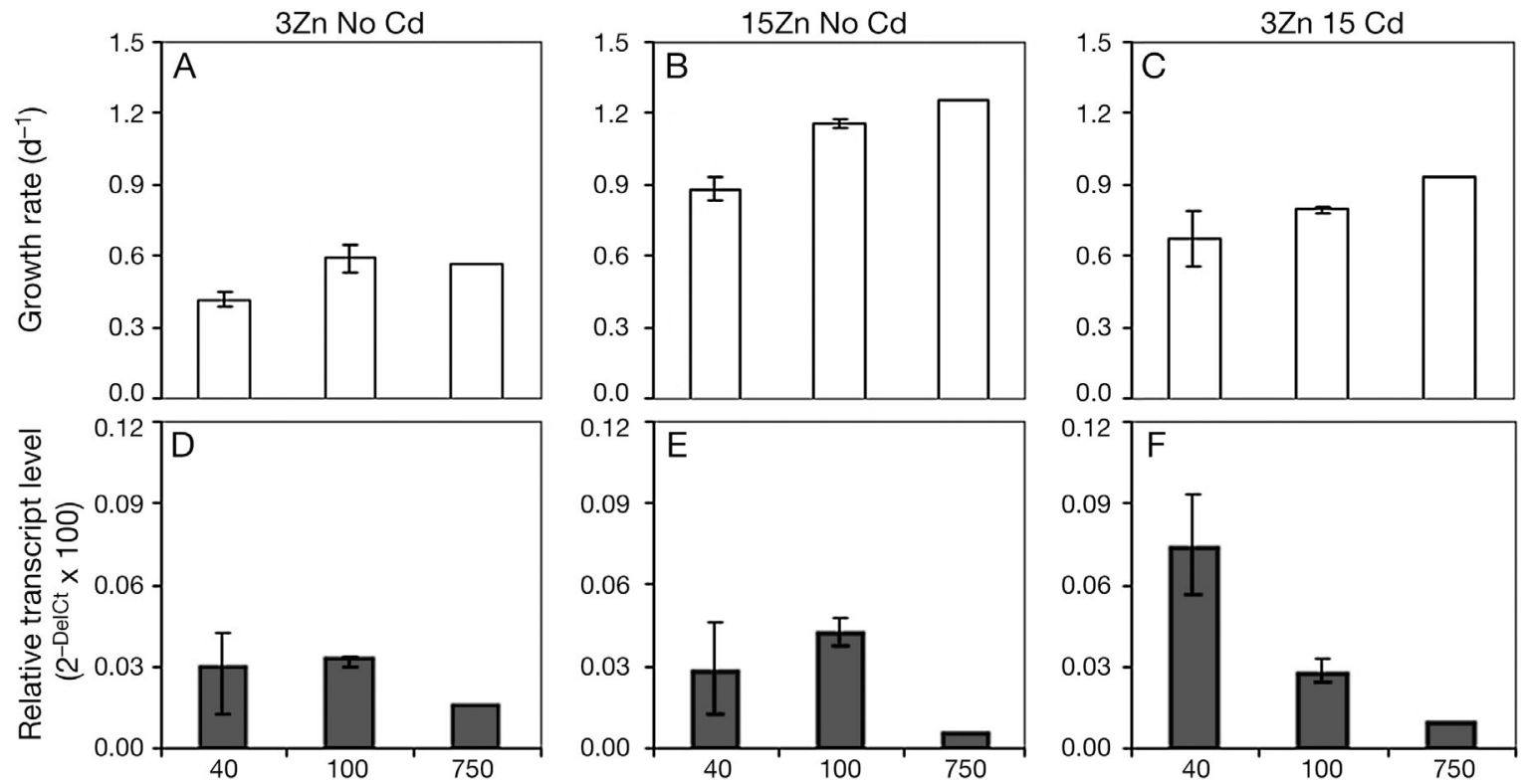

Fig. 1. Thalassiosira weissflogii. (A-C) Growth rate and (D-F) abundance of cdca1 transcript relative to 18S rRNA of cultures grown under different metal and $p \mathrm{CO}_{2}$ conditions in Aquil medium. Experiments are grouped according to metal conditions: 3Zn No Cd (3 pM Zn', no Cd added: A, D); 15Zn No Cd (15 pM Zn', no Cd added: B, E); and 3Zn 15Cd (3 pM Zn', 15 pM Cd': C, F). Values are mean of 2 independent experiments and error bars represent the range of observed values 
and 8.4, corresponding $p \mathrm{CO}_{2}=280$ and 220 ppm) cultures growing at a constant growth rate were amended with 15 pM Cd'. Following the $\mathrm{Cd}$ addition, we measured over time both the expression of cdca1 by qRTPCR and the CDCA1 concentration by semi-quantitative western blotting. The addition of $\mathrm{Cd}$ resulted in an increase of about $20 \%$ in growth rate in $24 \mathrm{~h}$, compared to the no $\mathrm{Cd}$ addition in both experiments (data not shown). The quantified cdca1 transcript numbers increased by a factor of 2 over the first $4 \mathrm{~h}$ following $\mathrm{Cd}$ addition, decreasing afterwards to a value 30\% higher than the background level (Fig. 2). The enzyme concentration measured by western blotting analysis increased gradually over time, reaching nearly twice the initial value after $24 \mathrm{~h}$ (Fig. 2). We report here the absolute copy numbers of cdca1 transcripts instead of the relative abundance of cdca1 transcripts normalized to 18S rRNA, as $4 \mathrm{~h}$ following Cd-EDTA addition the 18S rRNA copy number went down by a factor of 5 to 10 before returning to its initial level after $24 \mathrm{~h}$. This may indicate that the $\mathrm{Cd}$ addition initially resulted in a transient toxic effect on the cells (Pinto et al. 2003, Valko et al. 2005), which was then
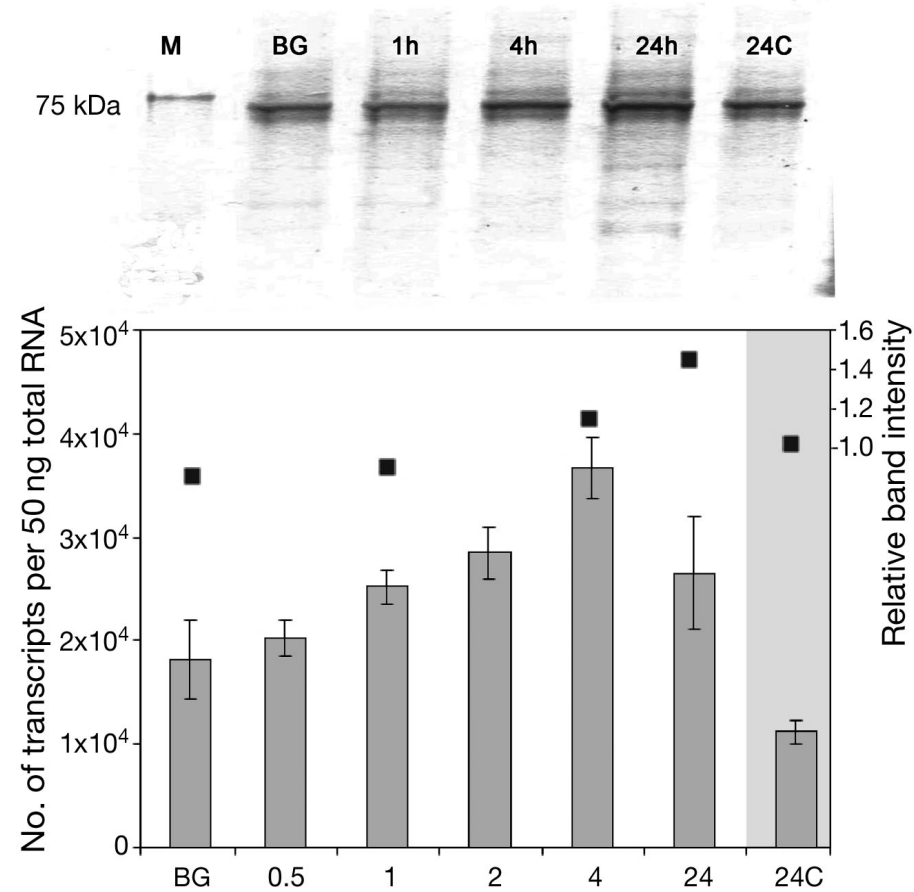

Fig. 2. Thalassiosira weissflogii. Absolute copy numbers of cdca1 transcript and scanned image of western blotting on CDCA1 protein of 2 separate Cd-EDTA addition experiments. Bar graphs indicate the mean transcript numbers of 2 experiments. Error bars represent the range of observed transcript numbers from the 2 experiments. ' $\mathrm{M}$ ' is a $75 \mathrm{kDa}$ molecular marker. 'BG' and ' $24 \mathrm{C}^{\prime}$ are control cultures that were not amended with $\mathrm{Cd}$, and which were collected at time 0 and $24 \mathrm{~h}$, respectively. (ם) Relative band intensity of western blotting (right axis) alleviated by some physiological response, such as the synthesis of phytochelatin and binding of Cd (Thumann et al. 1991, Wei et al. 2003). We conducted control experiments in which Zn-EDTA (up to Zn' = 10 pM) or EDTA by itself was added to low Zn cultures and followed the change of mRNA expression over $24 \mathrm{~h}$. As expected, Thalassiosira weissflogii growth rate increased from 0.35 to $0.5 \mathrm{~d}^{-1} 24 \mathrm{~h}$ after Zn-EDTA addition and did not change in cultures amended with EDTA only. There was no change in the cdca1 transcript levels under either of these conditions (data not shown).

We also performed time-course experiments where we changed the $p \mathrm{CO}_{2}$ in cultures of Thalassiosira weissflogii grown with $\mathrm{Cd}$ at low $\mathrm{Zn}$ concentration $\left(\mathrm{Cd}^{\prime}=15 \mathrm{pM} ; \mathrm{Zn} \mathrm{n}^{\prime}=3 \mathrm{pM}\right)$ by changing the $\mathrm{CO}_{2}$ composition of bubbled air. Upon a decrease of $p \mathrm{CO}_{2}$ from $750 \mathrm{ppm}$ to $100 \mathrm{ppm}$, the CDCA1 transcript level increased by a factor of 3 in $2 \mathrm{~h}$, and remained constant afterwards (Fig. 3A, grey bars). A shorter-term experiment in which $p \mathrm{CO}_{2}$ level was decreased by base addition (increasing $\mathrm{pH}$ from 7.8 to 8.5 ), rather than bubbling with low- $\mathrm{CO}_{2}$ air, gave essentially the same result after $1 \mathrm{~h}$, with an overshoot of the transcript level after a half hour (Fig. 3A, hatched bars). In another experiment, we increased $p \mathrm{CO}_{2}$ from $40 \mathrm{ppm}$ to $350 \mathrm{ppm}(\mathrm{pH} 9.1$ to $\mathrm{pH} 8.1$ ) by the addition of acid to a T. weissflogii culture grown at high $\mathrm{Cd}$ with low $\mathrm{Zn}$ as above. After $2 \mathrm{~h}$, the transcript level of cdca1 decreased by a factor of 3 (Fig. 3B). The magnitude of the changes in the level of expression observed in these experiments is consistent with the differences in cdca1 mRNA expression observed under different $p \mathrm{CO}_{2}$ at steady state (Fig. 1F). The relative change in cdca1 expression induced by changing the $p \mathrm{CO}_{2}$ and the kinetics of that change are also comparable to those observed in the expression of twca1, the other CA enzyme identified in T. weissflogii (Lane \& Morel 2000b). Unlike what happened during the $\mathrm{Cd}$ addition experiments, the transcript level of the 18S rRNA housekeeping gene remained essentially constant during the $\mathrm{CO}_{2}$ increase and decrease experiments.

\section{CDCA in the Equatorial Pacific}

Since the enzyme is apparently expressed under Znlimiting conditions, we first attempted to find evidence of CDCA expression in the field during a cruise to the Equatorial Pacific in October 2005. The surface waters of the Equatorial Pacific are known to have very low concentrations of many trace metals, including $\mathrm{Zn}$, which has been measured at less than $0.2 \mathrm{nM} \mathrm{Zn}_{\mathrm{T}}$ (Bruland 1989). At 11 stations (Fig. 4) we extracted DNA from filtrates of surface samples and tested them for the presence of cdca genes using the same degen- 


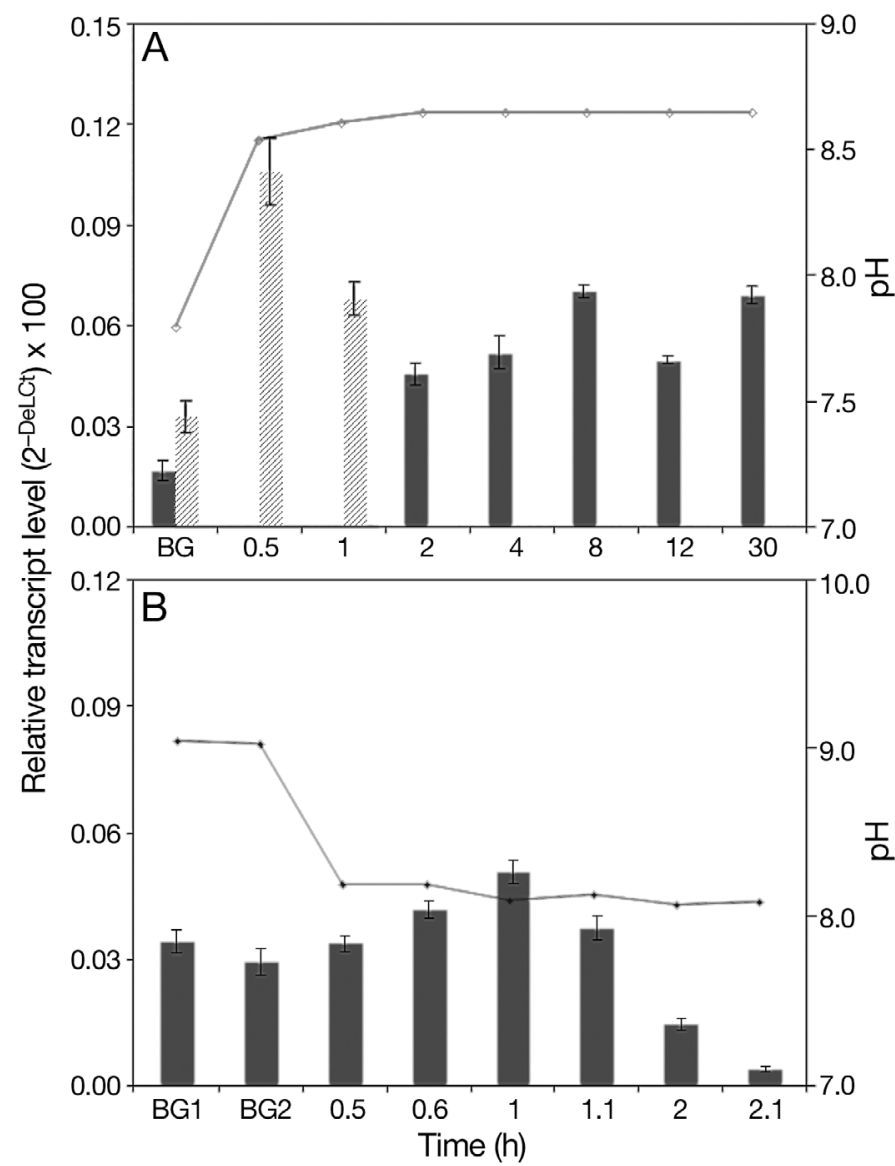

Fig. 3. Thalassiosira weissflogii. (A) Induction of cdca1 transcripts (bars) by changes in $\mathrm{pH} / p \mathrm{CO}_{2}$ (line). Gray bars: $p \mathrm{CO}_{2}$ was changed at time 0 by bubbling low $p \mathrm{CO}_{2}$ air (reducing $p \mathrm{CO}_{2}$ from $750 \mathrm{ppm}$ [BG] to $100 \mathrm{ppm}$ ). Hatched bars: $\mathrm{pH}$ was changed at time 0 by adding base (raising $\mathrm{pH}$ from 7.5 [BG] to 8.6). (B) Repression of cdca1 transcripts (bars) by changes in $\mathrm{pH}$ or $\mathrm{pCO}_{2}$ (line). $\mathrm{pH}$ was lowered at time 0 by the addition of acid ( $\mathrm{pH}$ from 9.1 [BG1 \& BG2] to 8.1). Error bars in both panels are $1 \mathrm{SD}$ of quadruplicate q-PCR wells

erate primers as in Park et al. (2007). DNA extracts from 5 stations relatively close to the Peruvian coast (Fig. 4) yielded positive results and we were able to amplify 39 new cdca-like genes. Phylogenetic analysis shows that these new derived amino acid sequences clusters principally in 2 groups: one with very high similarity ( $>90 \%$ identity) to sequences previously obtained from coastal NJ samples; and another, more diverse set that clusters with the sequences from cultured centric diatoms (Fig. 5). Our inability to amplify cdca-like sequences in the samples from the other stations may have been caused as much by the low biomass collected in several of these samples (particularly at the open ocean sites) as by the inadequacy of our primers or the absence of the cdca gene.

We also collected biomass for RNA from surface seawater samples at Stns 24 and 31, as well as from samples from 3 stations $(9,26$ and 35) incubated on deck with additions of $\mathrm{Cd}$ and $\mathrm{NaOH}$ to bring the $\mathrm{pH}$ to 8.6 (Fig. 4). Unfortunately, we were unable to identify cdca mRNA in any of these samples. Unexpectedly, our attempts to identify CDCA turned out to be most successful using immunological techniques rather than qRT-PCR. A sample collected at Stn 9, which was close to shore with a moderately high chl a concentration $\left(15.6 \mu \mathrm{g} \mathrm{l}^{-1}\right)$ was incubated on deck for $5 \mathrm{~h}$, with the addition of $\mathrm{Cd}$ at ambient $p \mathrm{CO}_{2}(\mathrm{pH}=8.0)$. Western blotting analysis revealed a faint band at a molecular mass around $\sim 70 \mathrm{kDa}$ that seemed to match the band obtained from Thalassiosira weissflogii cultures (Fig. 6A). A control sample incubated on deck for $8 \mathrm{~h}$ without $\mathrm{Cd}$ addition yielded no visible band. At Stn 26, where the biomass was also relatively high (chl $a=$

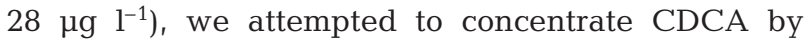
immunoprecipitation from both an ambient sample of seawater and a sample incubated on deck for $2 \mathrm{~h}$ at low $p \mathrm{CO}_{2}(\mathrm{pH}=8.6$, about 0.6 units higher than the ambient $\mathrm{pH}$ ). Western blotting analysis of the immunopre-

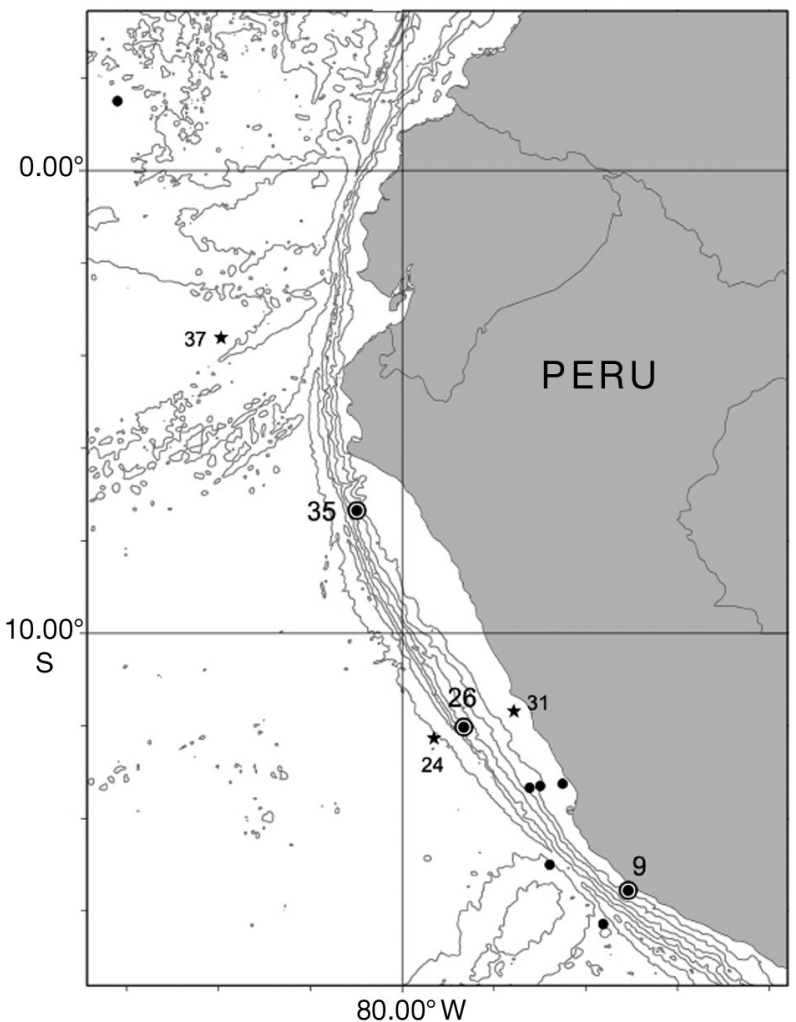

Fig. 4. Study sites in the Equatorial Pacific near the Peruvian coast where surface seawater samples were collected during the austral spring of 2005 (October 18-November 10). •: stations where samples were analyzed for DNA but no cdca-like genes were found. $\star$ : stations where cdca-like genes were found; cdca-like genes were also found at Stns 9 and 35. O: stations where samples were incubated on deck with either Cd (Stn 9) or $\mathrm{NaOH}(\mathrm{Stn} 26)$ or both (Stn 35) 


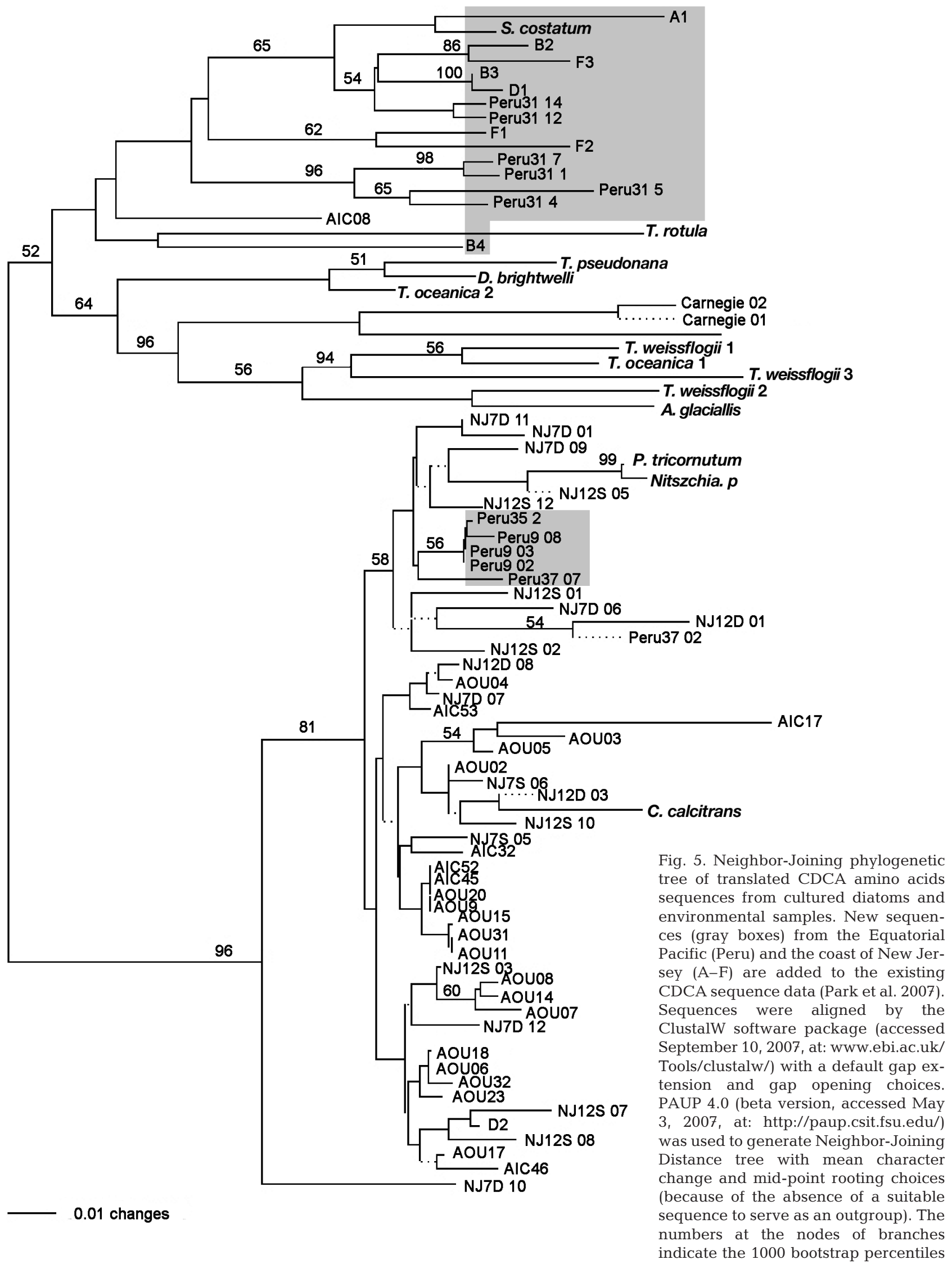



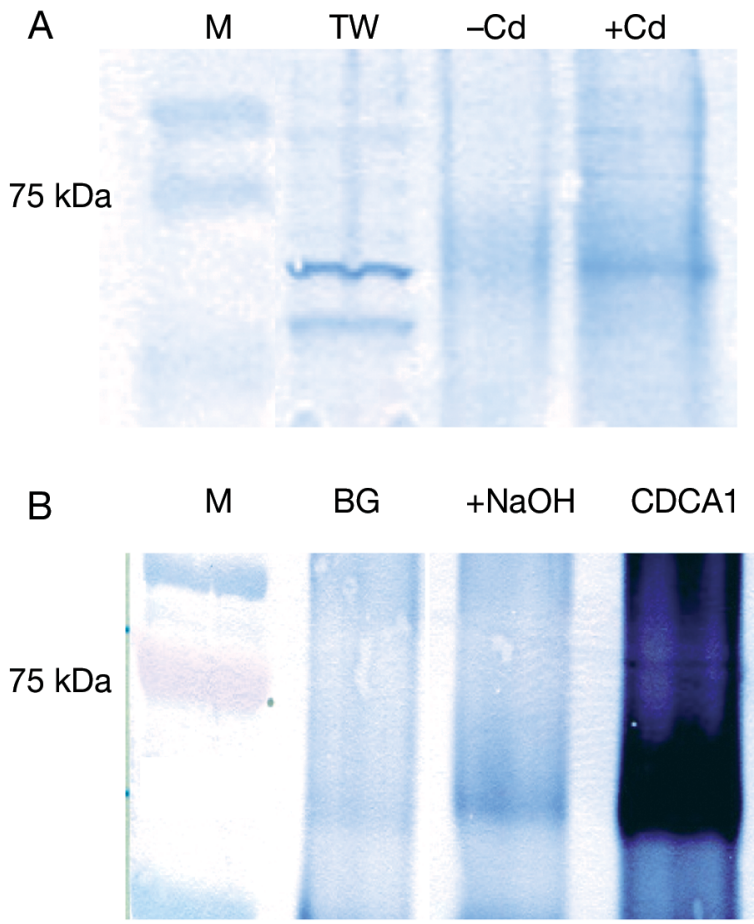

C MASSGWQAEI VTEFSLLNEM VDVDPQGILK CVDGRGSDNT QFCGPKMPGG IYAIAHNRGV TTLEGLKQIT KEVASKGHVP SVHGDHSSDM LGCGFFKLWV TGRFDDMGYP RPQFDADQGA KAVENAGGVI EMHHGSHAEK VVYINLVENK TLEPDEDDQR FIVDGWAAGK FGLDVPKFLI AAAATVEMLG GPKKARIVIP SISPAQIAEA LQGRGWDAEI VTDXSMAGQL VDVRPEGILK CVDGRGSDNT RMGGPKMPGG IYAIAHNRGV TSIEGLKQIT KEVASKGHLP SVHGDHSSDM LGCGFFKLWV TGRFDDMGYP RPQFDADQGA NAVKDAGGII EMHHGSHTEK VVYINLLANK TLEPNENDQR FIVDGWAADK FGLDVPKFLI AAAATVEMLG GPKNAKIVVP SITPPQIVSA LRGRGWKASI VKASTMSSEL KRVDPQGILK CVDGRGSDNT QFGGPKMPGG IYAIAHNRGV TTLEGLKDIT REVASKGHVP SVHGDHSSDM LGCGFFKLWL TGRFDDMGYP RPEFDADQGA LAVRAAGGVI EMHHGSHEEK VVYINLVSGM TLEPNEHDQR FIVDGWAASK FGLDVVKFLV AAAATVEMLG GPKKAKIVIP

Fig. 6. (A) Western blotting (50 $\mu \mathrm{g}$ of protein per lane) from on-deck incubated surface seawater samples collected at Stn 9. TW: protein extract of Thalassiosira weissflogii, $-\mathrm{Cd}$ : protein sample from surface seawater incubated for $8 \mathrm{~h}$ with no added $\mathrm{Cd}_{;}+\mathrm{Cd}$ : protein sample from surface seawater incubated with Cd-EDTA $(0.4 \mathrm{nM})$ for $5 \mathrm{~h}$. A faint band at the expected molecular mass $(\sim 70 \mathrm{kDa})$ was found on polyacrylamide gel electrophoresis (PAGE) from the incubated seawater sample. (B) Western blotting following immunoprecipitation and peptide sequences after internal peptide sequencing from on-deck incubated surface seawater samples collected at Stn 26. BG: proteins from ambient seawater. +NaOH: proteins from base-incubated seawater. CDCA1: partially purified CDCA1 as positive control. Faint bands at the expected molecular mass were found in both ambient and incubated samples. (C) Peptide sequences of bands from ambient and incubated samples excised after PAGE and analyzed by $2 \mathrm{D}-\mathrm{LC}-\mathrm{MS} / \mathrm{MS}$ method. Letters represent amino acids. SEQUEST algorithm was used for identification of proteins. About $30 \%$ of peptide fragments (at least 7 residues in length, in red) matched exactly to the CDCA1 sequence of $T$. weissflogii used as reference sequence (in black)
A
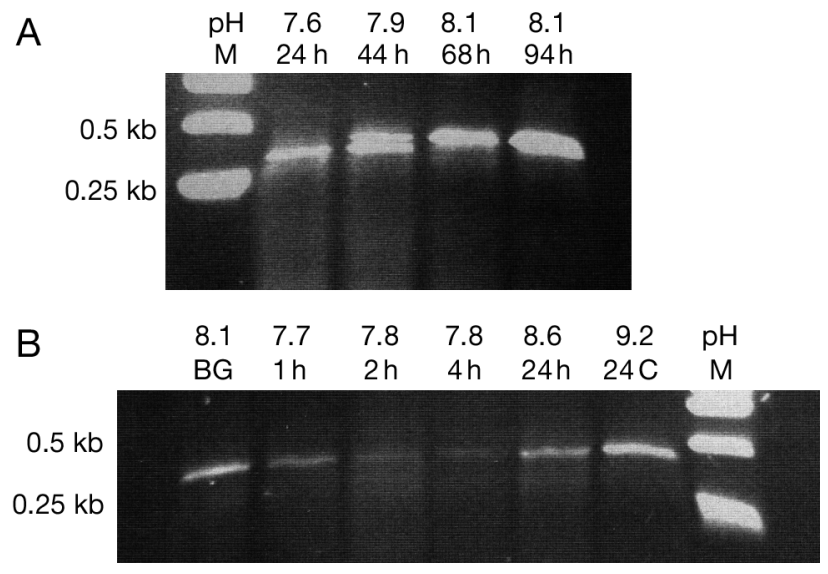

Fig. 7. RT-PCR products from coastal New Jersey samples run on $1 \%$ agarose gel. (A) RT-PCR products from natural $\mathrm{pH}$ increase experiment. The intensity of RT-PCR products of expected length (418 bp) increased as $\mathrm{pH}$ increased. (B) RT-PCR products from $\mathrm{pH}$-lowering/raising experiment (see text). The intensity of RT-PCR products of expected length (418 bp) systematically increased with $\mathrm{pH}$

cipitated sample dissolved in phosphate-buffered saline also revealed a faint band at the right molecular mass in the ambient seawater sample and a more visible band in the incubated seawater sample (Fig. 6B). We performed internal peptide sequencing of a sample pooled from the 2 bands excised from the $10 \%$ SDS polyacrylamide gel after electrophoresis. We found 21 distinct sequences that perfectly match CDCA1 sequences from T. weissflogii. In total, those sequences represent $30 \%$ of the total sequence of CDCA1 protein from $T$. weissflogii, leaving no doubt that this sample of surface water from Equatorial Pacific contains CDCAlike protein (Fig. 6B).

Though clearly incomplete, our results from the Equatorial Pacific samples establish that CDCA is expressed in this region of the ocean after an upwelling event and seems to confirm that low $p \mathrm{CO}_{2}$, and perhaps high $\mathrm{Cd}$ concentration both increase CDCA expression in laboratory cultures and in the field.

\section{Detection of CDCA expression in coastal New Jersey waters}

Although we expected CDCA to be expressed by diatoms chiefly under conditions of low Zn concentrations, our previous study revealed cdca-like genes at a coastal New Jersey site (Park et al. 2007). If these genes were expressed, we should be able to perform qRT-PCR analysis of samples from this site with our primer sets. The higher biomass in coastal New Jersey compared to the Equatorial Pacific should also be helpful. We collected samples from Great Bay in Southern 
New Jersey in May 2007 and incubated them in the laboratory under various conditions. The ambient seawater had a pH of 7.46 and is known to have high metal concentrations $\left(\mathrm{Zn}_{\mathrm{T}} \approx 10 \mathrm{nM}\right.$ and $\mathrm{Cd}_{\mathrm{T}} \approx 0.26 \mathrm{nM}$; Field et al. 1999). The presence of fucoxanthin and lack of additional accessory pigments (19-hexonyloxyfucoxanthin, 19-butanoyloxyfucoxanthin, and peridinin) indicated that this flora was primarily dominated by diatoms (chl $a=0.03 \mu \mathrm{g} \mathrm{l}^{-1}$ and fucoxanthin = $0.03 \mu \mathrm{g} \mathrm{l}^{-1}$ ).

In unamended water samples, the $\mathrm{pH}$ gradually increased from 7.5 to 8.1 in $4 \mathrm{~d}$ as a result of the utilization of $\mathrm{CO}_{2}$ by the growing phytoplankton. Most of the growth was due to diatoms as indicated by the high fucoxanthin concentration $\left(17.3 \mu \mathrm{g} \mathrm{l}^{-1}\right)$ measured after 3 d. Subsamples analyzed by RT-PCR (using cdca_418 primers, Park et al. 2007) yielded 2 amplicons near 418 bp whose band intensity increased with time and $\mathrm{pH}$ as quantified on the agarose gel (Fig. 7A).

In another experiment, after incubating a sample for $4 \mathrm{~d}$, we decreased its $\mathrm{pH}$ from 8.1 to 7.6 by addition of EPPS buffer. The intensity of amplified cDNAs bands after RT-PCR (30 cycles of amplification) with cdca_418 primers decreased within $1 \mathrm{~h}$ (Fig. 7B) and increased again after $24 \mathrm{~h}$, when the $\mathrm{CO}_{2}$ drawdown by the growing cells overcame the buffer capacity and the $\mathrm{pH}$ increased to 8.6. In this experiment, where the $\mathrm{pH}$ went up and down at various times, the level of expression of cdca (as measured by the band intensity of amplified cDNA) varied systematically with the $\mathrm{pH}$ change (Fig. 8A).

In similar incubation experiments, where we either let the $\mathrm{pH}$ vary naturally over time or buffered it with EPPS, we measured the CA activity of the sample and the concentration of CDCA by quantitative western blot analyses. Both measurements showed a systematic increase over the same range of $\mathrm{pH}$ as the increase in CDCA expression (Fig. 8B,C), although the increase in $\mathrm{CA}$ activity may be caused by the expression of other CAs along with CDCA.

While we originally thought that CDCA would only be found under conditions of low $\mathrm{Zn}$ concentration and low $p \mathrm{CO}_{2}$, this is clearly not the case. It turned out to be much easier to demonstrate the presence of CDCA in metal-rich New Jersey coastal waters than in the metal-poor Equatorial Pacific. Undoubtedly, part of the reason is simply the higher biomass of the coastal samples, which yield higher RNA and protein concentrations. But it seems surprising that diatoms in Zn-rich coastal water would express a Cd-centered CA. This unexpected finding is presumably explained by the recent results of $\mathrm{Xu}$ et al. (2008), which showed that CDCA is actually a cambialistic enzyme, able to use either $\mathrm{Zn}$ or $\mathrm{Cd}$ as its metal center. Further research will clearly be needed to establish what metal actually
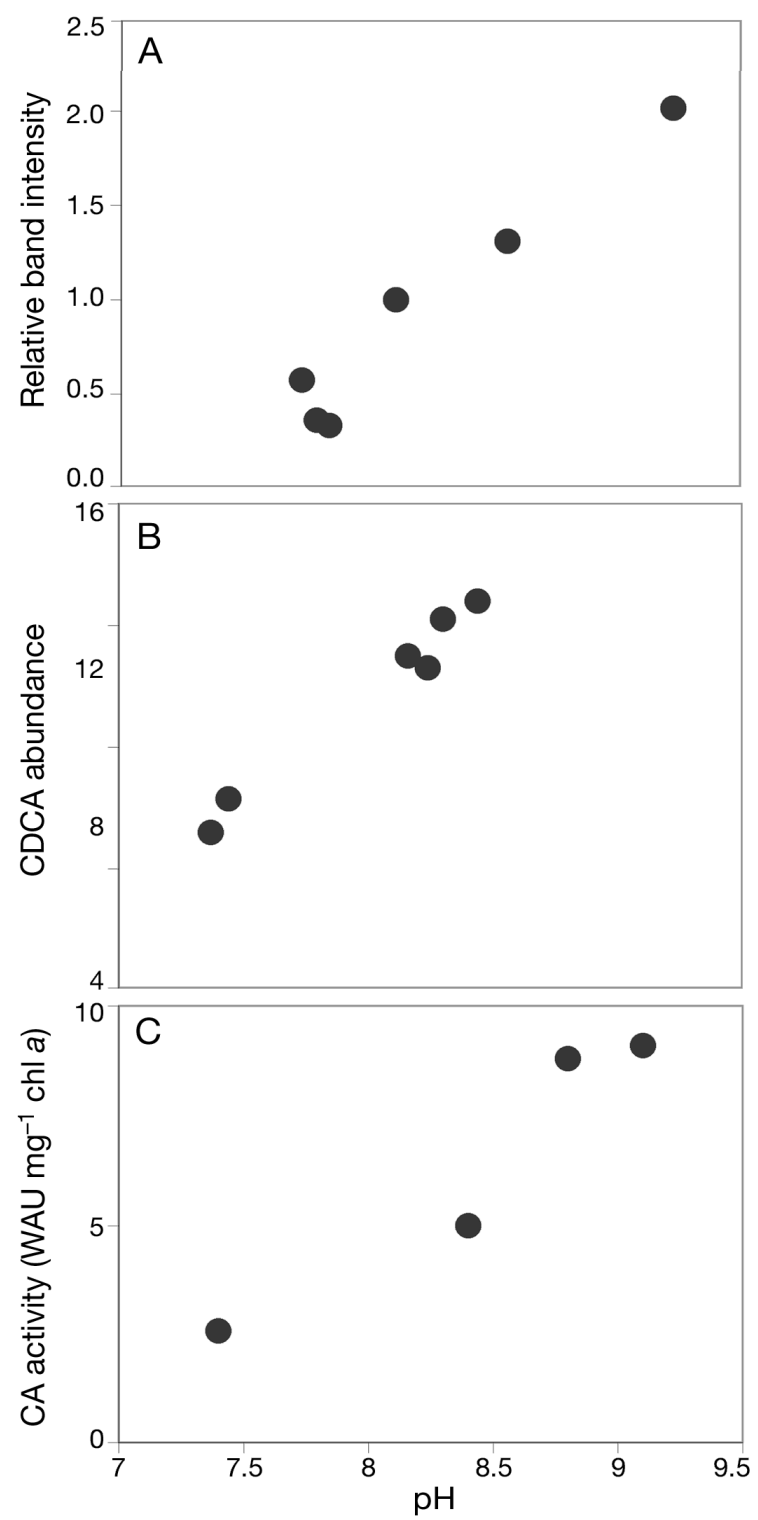

Fig. 8. Expression of CDCA as a function of pH. (A) Re-plotted relationship between $\mathrm{pH}$ and the relative band intensity of RT-PCR products from Fig. 7. (B) Relationship between pH and band intensity of CDCA proteins from a quantitative western blotting in Great Bay samples. (C) Relationship between $\mathrm{pH}$ and total carbonic anhydrase activity in (Wilbur Andersen, Units, WAU) Great Bay samples

serves as the center of the CDCA expressed in various parts of the oceans. In view of our data, we hypothesize at this point that a $\mathrm{Zn}$ form of CDCA is expressed in $\mathrm{Zn}$-rich coastal waters and that $\mathrm{Zn}$ is substituted by $\mathrm{Cd}$ only under low Zn conditions, as encountered in the open ocean. Interestingly, all our data indicate that the expression of CDCA in marine waters is finely modulated as a function of the ambient $p \mathrm{CO}_{2}$, implying a critical role for this enzyme in the acquisition of inorganic carbon by the ambient phytoplankton. 
Acknowledgements. We thank Dr. J. Moffett for organizing the research cruises to the Equatorial Pacific in fall 2005. We also thank the captain and crew of the RV 'Knorr' for their assistance during the cruises. Special thanks to $\mathrm{S}$. John from the Massachusetts Institute of Technology and C. Dupont from the University of California, San Diego, for the collection of trace-metal clean seawater; and to S. Kyin and H. Shwe at the mass spectrometry facility, Department of Molecular Biology, Princeton University, for peptide sequencing. We also thank T. W. Shawa, Geoscience Library, Princeton University, for generating the geological map of study sites, and B. Hopkinson, Princeton University, for pigment analysis of the coastal New Jersey samples. This work was supported by the Center for Environmental Bioinorganic Chemistry (NSF grant 0221978) and NSF grant 0351499.

\section{LITERATURE CITED}

Armbrust EV, Berges JA, Bowler C, Green BR and others (2004) The genome of the diatom Thalassiosira pseudonana: ecology, evolution, and metabolism. Science 306: 79-86

Badger MR, Andrews TJ, Whitney SM, Ludwig M, Yellowlees C, Leggart W, Price GD (1998) The diversity and coevolution of Rubisco, plastids, pyrenoids and chloroplast-based $\mathrm{CO}_{2}$ concentrating mechanisms in algae. Can $\mathrm{J}$ Bot 76: 1052-1071

Bruland KW (1989) Complexation of zinc by natural organicligands in the Central North Pacific. Limnol Oceanogr $34: 269-285$

Crawford DW, Lipsen MS, Purdie DA, Lohan MC and others (2003) Influence of zinc and iron enrichments on phytoplankton growth in the northeastern subarctic Pacific. Limnol Oceanogr 48:1583-1600

Delahunty C, Yates JR III (2005) Mass spectrometry in proteomics. Methods 35:248-255

Field MP, Cullen JT, Sherrell RM (1999) Direct determination of 10 trace metals in 50uL samples of coastal seawater using desolvating micronebulization sector field ICP-MS. J Anal At Spectrom 14:1425-1431

Hurt RA, Qiu XY, Wu LY, Roh Y, Palumbo AV, Tiedje JM, Zhou JH (2001) Simultaneous recovery of RNA and DNA from soils and sediments. Appl Environ Microbiol 67: 4495-4503

Editorial responsibility: Patricia Glibert, Cambridge, Maryland, USA
Lane TW, Morel FMM (2000a) A biological function for cadmium in marine diatoms. Proc Natl Acad Sci USA 97: 4627-4631

> Lane TW, Morel FMM (2000b) Regulation of carbonic anhydrase expression by Zinc, Cobalt, and carbon dioxide in the marine diatom Thalassiosira weissflogii. Plant Physiol 123:345-352

Lane TW, Saito MA, Georget GN, Pickering IJ, Prince RC, Morel FMM (2005) A cadmium enzyme from a marine diatom. Nature 435:42

> Moroney JV, Bartlett SG, Samuelsson G (2001) Carbonic anhydrases in plants and algae. Plant Cell Environ 24: 141-153

> Park H, Song B, Morel FMM (2007) Diversity of cadmium containing carbonic anhydrase in marine diatoms and natural waters. Environ Microbiol 9:403-413

Pfaffl MW (2001) A new mathematical model for relative quantification in real-time RT-PCR. Nucleic Acids Res 29:e45

$>$ Pinto E, Sigaud-Kutner TCS, Leitao MAS, Okamoto OK, Morse D, Colepicolo P (2003) Heavy metal induced oxidative stress in algae. J Phycol 39:1008-1018

Porra RJ, Thompson WA, Kriedemann PE (1989) Determination of accurate extinction coefficients and simultaneousequations for assaying chlorophyll-a and chlorophyll-b extracted with 4 different solvents-verification of the concentration of chlorophyll standards by atomic-absorption spectroscopy. Biochim Biophys Acta 975:384-394

Roberts SB, Lane TW, Morel FMM (1997) Carbonic anhydrase in the marine diatom Thalassiosira weissflogii (Bacillariophyceae). J Phycol 33:845-850

Sunda WG, Price NM, Morel FMM (2005) Trace metal ion buffers and their use in culture studies. In: Anderson R (ed) Algal culturing techniques. Elsevier Academic Press, p 35-63

Thumann J, Grill E, Winnacker EL, Zenk MH (1991) Reactivation of metal-requiring apoenzymes by phytochelatinmetal complexes. FEBS Lett 284:66-69

Valko M, Morris H, Cronin MTD (2005) Metals, toxicity and oxidative stress. Curr Med Chem 12:1161-1208

Wei LP, Donat JR, Fones G, Ahner BA (2003) Interactions between $\mathrm{Cd}, \mathrm{Cu}$ and $\mathrm{Zn}$ influence particulate phytochelatin concentrations in marine phytoplankton: laboratory results and preliminary field data. Environ Sci Technol 37:3609-3618

Xu Y, Feng L, Jeffrey PD, Shi Y, Morel FMM (2008) Structure and metal exchange in the cadmium carbonic anhydrase of marine diatoms. Nature 452:56-61

Submitted: January 4, 2008; Accepted: March 3, 2008 Proofs received from author(s): May 6, 2008 